\title{
Media, Power and the Pandemic: Production of Fear, Discipline and a Distraught Self
}

Saravanan Velusamy is an M.Phil. Candidate at the Center for the Study of Social Systems, Jawaharlal Nehru University, New Delhi.

\section{Abstract}

Pandemic needs a globalized world where we have to live with the risks that come with it. Television is a crucial communication device that shapes public perception and mediates our comprehension of the outside world. It also forms part of the ideological apparatus that aids in reproducingthe dominant perception of reality among the masses. This article is based on observations made of the TRPdriven TV content produced during the lockdown period, in order to interpret the meaning that a projected reality produces. The article intertwines both: how government uses television to bring order as they tackle the situation and how advertisement on the other hand promote sales during crisis, both of which tries to convince the 'consumer-citizen' that these are extraordinary times but normalcy is returning. The objective of this paper is to understand the role of media during pandemic times and decipher the kind of self it produces given its strong influence in interpreting the world for its viewers.

Key Words: TRP-driven media, power, pandemic, fear and discipline, self.

\section{Introduction}

The contagious and the life-threatening COVID-19 have caused havoc in the lives of ordinary citizens in India. The shutting down of business operations during lockdown and heavily restricted interdistrict and inter-state movement had put the economy in a limbo. Jobs and livelihoods were lost as the Prime Minister called for greater self-reliance. Clearly, the fear of likely infection by the virus did not baffle them as much as the fear of losing their livelihoods and the fear of uncertainty that loomed large. Lockdown was a drastic step to control the virus for a country that run on migrant laborers and 


\section{4 / Saravanan Velusamy}

Salesian Journal of Humanities and Social Sciences, Vol. XI, No.2 (Dec 2020)

ISSN: 0976-1861 | DOI: 10.51818/SJHSS.11.2020.13-33 | Page: 13-33,

Section: Articles

daily-wage workers. Such measures expose state display of power and imposition of control in a democracy.

People in India were still trying to make sense of the catastrophe that confront them. They were glued to their television screens for daily updates on the infection rates, the relief measures taken and the new regulations that would form part of the new normal. Television media gained greater significance during lockdowns. The stories of tragic events that television brought home daily confirmed of the kind of risk society we have built, the consequences of which would be borne by generations to come. According to Ulrich Beck, the systematic accumulation of risk an industrial society produces in the process of wealth creation often affects the vulnerable sections the most and cause irreversible harm to the society as a whole. ${ }^{1}$ Do citizens as political subjects have the reflexive capacity to understand the structural conditions that produce risks? Is public engagement during the pandemic possible amidst the noisy distractions produced by the television media? Can citizens think critically despite the information overload? How do we understand the distressed subjectivities that pandemic and its everyday telecasting produce? This article does not intend to answer these questions necessarily but provide reasons and interpretations to emphasize on their relevance and significance for our times.

The objective of this paper is to understand the role of media during pandemic times and interpret the meaning based on how it fashions itself and how it presents before us. Through its agenda-setting function and production of news and entertainment content, television media especially the popular onesby catering to its audience also shapes them. This article uses an interpretativedeductive framework to comprehend media behavior and state response during pandemic times in India.

Mass media can be Janus-faced in that it can act as an agent fostering democratic ideals (keeping the public informed) yet

1 For more discussions on Beck's idea of 'risk society' see https://www. sciencedirect.com/topics/social-sciences/risk-society. 
undermine the same by disempowering the individuals through creating disorientation in them. Television mediates this process as a mass communication device to keep the public informed about the health crisis and at the same time keeping them engaged (or disengaged). The institution of media has heterogeneous actors. A few News editors and Media channels (national and regional), including those independent ones that operate via alternative digital platforms, did keep up with their ground reporting on Covid-19 outbreak and how the humanitarian crisis unfolded thereafter. Yet, the TRP-driven news channels, often pro-government in their approach, did divert a lot of attention away from the tragedy that the pandemic brought. In this article, I intend to discuss TRP Media's potential to keep the distraught individual subjects into a homogenized lot of docile selves, as most of the TV channels hadalready resumed with their news and general entertainment programming.

Although, information is a significant tool to safeguard us from the virus, the kind of television contents one was exposed to on a daily basis and how they have been framed and packaged, all do influence and shape viewers' perception and behavior. As a conduit of ideas and messages, television particularly is a crucial medium especially during the times of a pandemic-induced lockdown - since they become their only window to the world. One of the arguments of this paper is that citizens especially the poor, internalized fear and discipline to stay indoors and to comply with the state orders. Thiswas made possible through everyday broadcasting of 'state responses' to the rapid spread of the virus. People realized gradually that these were no ordinary times. Thanks to the pervasive presence of media, viewer-citizens could bear witness to a certain 'spectacle of disaster' to use Baudrillard's phrase, that makes them experience fear as local as it is global and as simulated as it is real. ${ }^{2}$ Baudrillard

\footnotetext{
2 These arguments are developed from a blog post the author wrote earlier. See S. Velusamy, "Media In Pandemic Times: Fear, Discipline And Commercial Breaks," Doing Sociology, May 25, 2020. Retrieved August 25 from https:// doingsociology2020.blogspot.com/2020/05/media-in-pandemic-times-statedemocracy.html
} 


\section{6 / Saravanan Velusamy}

Salesian Journal of Humanities and Social Sciences, Vol. XI, No.2 (Dec 2020)

ISSN: 0976-1861 | DOI: 10.51818/SJHSS.11.2020.13-33 | Page: 13-33,

Section: Articles

uses the phrase 'spectacle of disaster' as a media-simulated reality that dilutes its meaning and intensity wherein individuals lose their capacity to respond appropriately, leading to the 'the end of the social' and hence 'events' end up being mere signs, images and a spectacle. ${ }^{3}$ The disorientation produced acts as a barrier for consciousness awakening or collective action because the public starts internalizing the crisis and begin to look at it, in the words of the Finance Minister of India, 'as an act of god'.

The role of television media is significant here because while it produced anxiety and fear to manufacture consent among citizens as I argue here, it also engaged in the production of hope through public dissemination of critical health communication. In the pastevery time an epidemic breaks out - the coverage on media across the world has been overwhelmingly large, while most of them indicate circumstances to be fearful, others offered assurance and solace. Karin Wahl-Jorgensen, a professor in journalism who studies media reporting of the virus outbreak says, "the prominence of fear as a theme in reports of the coronavirus suggests that much of the coverage of the outbreak is more a reflection of public fear than informative of what is actually happening in terms of the spread of the virus." ${ }^{4}$ In India, while some media channels fostered scientific information and operated within standard procedures and journalistic ethics, others did not shy away from spreading misinformation and conspiracy theories. Initially, pro-government media channels in India even involved in religious profiling of the Covid-19 spread after the TablighiJamat conference. While viewers watched these with grief and anguish, the same television also distracted us with the glamour of reality shows, soap operas, the Mahabharata and Ramayana series and the kind of insidious commercial ads that deceives us into thinking that things are normal or getting normal. It is a truly schizophrenic moment.

${ }^{3}$ J. Baudrillard, Symbolic Exchange and Death, (London: Sage Publications, 1993), $87-100$.

\footnotetext{
${ }^{4} \mathrm{~K}$.Wahl-Jorgensen, “Coronavirus: how media coverage of epidemics often stokes fear and panic," The Conversation, April 15, 2020. Retrieved August 2, 2020 from https://theconversation.com/coronavirus-how-media-coverage-of-epidemicsoften-stokes-fear-and-panic-131844
} 
Media, Power and the Pandemic: Production ofFear, Discipline and a Distraught Self/17

Salesian Journal of Humanities and Social Sciences, Vol. XI, No.2 (Dec 2020)

ISSN: 0976-1861 | DOI: 10.51818/SJHSS.11.2020.13-33 | Page: 13-33,

Section: Articles

The wider and overwhelming coverage of state response to mitigate the virus spread as against covering the plight of the poor and the marginalized during the lockdown implies that much of the media serves the state and the market forces in India. Government tendency to unleash force upon the poor and repress unrest was not given sufficient attention whenever public action laid bare the discrepancies in governance, inadequacy of measures taken, and pointed out the existing fault lines in the governance of the crisis. Moreover, government action to incarcerate dissenting voices did not receive as much attention as most of the media stayed away from covering issues that hurt the ruling dispensation. ${ }^{5}$

Singh feared how democratic governments in India (both state and central) could take an autocratic turn if their behaviour goes uncriticized and unregulated. Media entities and reporters were asked by the BJP government to report news positively. Expecting the media to deliver Covid-19 news and government provided messages with a streak of positivity puts media freedom at jeopardy and could amount to direct influence upon news reportage. ${ }^{6}$ The kind of news stories selected, their relevance, emphasis and the comprehensiveness with which they were covered, ought to direct the viewers towards making informed opinion. These are important in determining how professional and fair a news media is. We also know how news coverage around an issue can turn public attention towards it and sustain their interest. The agenda-setting function of the media is crucial to influence public opinion and action towards resolving any issue at hand. ${ }^{7}$ On the other hand, by ways of brushing aside, misdirecting attention and diluting the significance of a topic or viewpoint, these dominating news channels (the TRPdriven media) exercise their power over their audience by choosing for them what news and narratives to consume. This way, the

${ }^{5}$ B. Singh, "Media in the Time of COVID-19," Economic and Political Weekly 55, 16(2020): 1-6.

'Sagar, "Speaking Positivity to Power," The Caravan, May 31, 2020. Retrieved July 26, 2020 from https:/ / caravanmagazine.in/media/hours-before-lockdownmodi-asked-print-media-owners-editors-refrain-negative-covid-coverage

${ }^{7}$ J.W. Dearing and E.M. Rogers, Agenda-setting, (Thousand Oaks, CA: Sage, 1996). 


\section{8 / Saravanan Velusamy}

Salesian Journal of Humanities and Social Sciences, Vol. XI, No.2 (Dec 2020)

ISSN: 0976-1861 | DOI: 10.51818/SJHSS.11.2020.13-33 | Page: 13-33,

Section: Articles

television media kept the populace more deceived and distracted both for commercial and ideological reasons making limited space for public engagement and critical reflection.

\section{Part I}

\section{Pre-Covid India and Media}

The media-prescribed view of reality around pandemic needs to be investigated in order to ascertain the levels to which it shapes the prevailing consciousness among the public. The idea of social imaginary, "the ways in which people imagine their social existence, how they fit together with others, how things go on between them and their fellows" is an important analytical tool to study the institution of media as an ideological apparatus of the state. ${ }^{8}$ The idea was borrowed from Anderson's idea of 'the imagined communities'. Social imaginaries help us understand constructed reality since imagination itself has become an organized field of social practice in the cultural realm. ${ }^{9}$

While the pre-covid India can be characterized by slowing economy, persistent agrarian crisis, record level of joblessness and declining labour force participation rate, ${ }^{10}$ much of the mainstream media that enjoys high TRP rates and state patronage, either turned a blind eye or diluted the gravity of the situation for its viewers. In other words, we were in disastrous circumstances even before the outbreak of the pandemic. TRP-driven Media garnered public support for the ruling governments that promised an idea of vikas(rhetoric of development), which also slowly dismantled critical public infrastructure over time, such as public distribution systems, public education, healthcare and essential transport necessary to save us from misfortunes such as these. In other words,

${ }^{8}$ Charles Taylor, Modern Social Imaginaries, (USA: Duke University Press, 2003), 23.

${ }^{9}$ A. Appadurai, Modernity al large: cultural dimensions of globalization, (Minnesota: University of Minnesota Press, 1996).

${ }^{10}$ Labor Force Participation rate is an indication of the number of people in working age looking for jobs. 
Media, Power and the Pandemic: Production ofFear, Discipline and a Distraught Self/ 19

Salesian Journal of Humanities and Social Sciences, Vol. XI, No.2 (Dec 2020)

ISSN: 0976-1861 | DOI: 10.51818/SJHSS.11.2020.13-33 | Page: 13-33,

Section: Articles

the discrepancies and fragilities of the pre-covid India haunted India under the lock down. While the rich has had the resources to insulate themselves from such risks, the rest of the society struggled to survive and cope up. The common masses in India are experiencing a pandemic of this scale for the first time and the abrupt decision to impose lockdown has not given them, especially the most vulnerable among them, the time to absorb the shock and prepare for it. Clearly, pandemic affected different sections of our population differently, often depending upon the social location they belong.

The domineering news channels in India-especially the progovernment ones-boasted about daily updates concerning the pandemic, often with more aggression and drama under the lockdown. The pressure to make the news industry survive by keeping the viewers' attention intact, galvanized their anchors to stage dramatic expositions that are nothing but dangerous insinuations. The way it incarcerated activists and students during prime time, popularly known as 'media trials' resonates the evolving mediascapes in India. Such an imposture goes unregulated as it serves the interest of the government and suits the post-truth society that has developed a general disregard for truth. The following section discusses the kind of notable changes that the world of news media in India underwent and their consequences for society.

How do we make sense of press freedom in India? India's ranking in the Press Freedom Index has only gotten worse every year with frequent arrests of journalists, police violations and increasing pressure for the media houses to toe the line of the Hindu nationalist agenda. ${ }^{11}$ The report also speaks about orchestrated social media hate campaigns against journalists in the country and the invoking of section 124a to charge sedition cases against journalists. ${ }^{12}$

\footnotetext{
${ }^{11}$ World Press Freedom Index 2020.

${ }^{12}$ World Press Freedom Index 2020.
} 


\section{0 / Saravanan Velusamy}

Salesian Journal of Humanities and Social Sciences, Vol. XI, No.2 (Dec 2020)

ISSN: 0976-1861 | DOI: 10.51818/SJHSS.11.2020.13-33 | Page: 13-33,

Section: Articles

\section{Corporate-driven}

What has led to this selective and profit-driven news reporting that is constantly in fear of the ruling order? Media houses are now controlled by major corporate houses engendering free and fair journalism in the country. ${ }^{13}$ P.Sainath, a senior journalist and the founder-editor of People's Archive for Rural India (PARI), observed that the mainstream media platforms such as National News channels in India might be politically free but are imprisoned by profits. ${ }^{14}$ Dependence on corporate and government-provided advertisement for revenue is central to news media and their deliberate reluctance and shying away from discussing the plight of people that puts the ruling dispensation in poor light.

\section{The menace of fake news}

Sixty-nine percent of Indians surveyed, mostly youngsters of the age group 18-25, fell prey to fake news during the lockdown as per a study by Social Media Matters and Institute for Governance, Policies and Politics-conducted recently. ${ }^{15}$ Of which, 88.41 per cent were spread via WhatsApp and Facebook and 70 per cent of the consumers did not even report that as fake news. From an independent ideologically-neutral entity to one of propaganda machinery, media (both print and TV) have undergone major shifts. New media provided novel platforms to inform and misinform, and to create, distort and share news events, forging the narrative to suit the ideology of one's vested interest or appeal to the beliefs held.

${ }^{13}$ V. Parthasarathi, \& A. Srinivas, "Problematic ownership patterns: the evolution of the television distribution networks in India," Economic $\mathcal{E}$ Political Weekly54, 12(2019). Retrieved August 15 https://www.epw.in/engage/article/televisionnetworks-political-ownership-patterns

${ }^{14}$ P. Sainath, "Politically Free, Imprisoned by Profit", $22^{\text {nd }}$ Safdar Hashmi Memorial Lecture, 2016, Newsclick. Retrieved May, 2020 from https://www.youtube.com/ watch?v=Nq-bBDw2r-Y (Part 1) and https://www.youtube.com/watch?v=FzWcPY9FAI (Part 2)

${ }^{15}$ See Tanurima Mitra, "Surveys on Fake News in the Times of Covid-19", Social Media Matters, 13 ${ }^{\text {th }}$ August, 2020. Retrieved August 15, 2020 fromhttps:/ /www. socialmediamatters.in/ surveys-on-fake-news-in-the-times-of-covid-19 
Media, Power and the Pandemic: Production ofFear, Discipline and a Distraught Self/ 21

Salesian Journal of Humanities and Social Sciences, Vol. XI, No.2 (Dec 2020) ISSN: 0976-1861 | DOI: 10.51818/SJHSS.11.2020.13-33 | Page: 13-33,

Section: Articles

Post-truth politics is understood as a phenomenon where debates are framed largely by appealing to the affective realms that is rooted in one's identity and sentiments, often disconnected or deviated from truth and reason. The new media of the digital sphere fall victim to such fake news. It is used as a propaganda tool by politicians for the scale of its reach and degree to which it shapes public opinion. These technologies were frequently employed by IT wings established by major political parties to control narrative and public opinion. Facts aremuddled when they are unfavorable and sometimes even doctored or fabricated to produce desired effects. Thetendency for hero-worship and the unquestionable status granted to the populist leaders also characterizes the posttruth phenomenon.

\section{Part II}

\section{Covid-19 and Media}

The section is based on reports on media and advertisements in India during lockdown. Television advertisements volume have increased by around 12 per cent during unlock periods (15-21 Aug 2020 and 11-17 April 2020) compared to the pre-covid volumes, according to a BARC (Broadcast Audience Research Council) India and Nielson report 2020. Top 10 advertisers inventory rose to 34 per cent during the unlock period compared to the pre-covid times. There has also been consistent rise in the advertisers and brands being advertised after May 2020. ${ }^{16}$ With the return of original programmes, their advertisers also returned during the unlock weeks. Advertisement volumes increased especially for FMCG(Fast-moving Consumer Goods), E-commerce and educational goods. The report also indicated, different genres were back to pre-covid levels (Jan-Feb 2020) and Ad views for news during prime time and movie time also saw a spike. ${ }^{17}$ Advertisement volumes in television saw a 6 per cent rise in June to August 2020 as against the same period last

${ }^{16}$ BARC India and Nielson Report 2020, 44.

${ }^{17}$ Ibid. 


\section{2 / Saravanan Velusamy}

Salesian Journal of Humanities and Social Sciences, Vol. XI, No.2 (Dec 2020)

ISSN: 0976-1861 | DOI: 10.51818/SJHSS.11.2020.13-33 | Page: 13-33,

Section: Articles

year, according to data released by AdEx India 2020. ${ }^{18}$ The crucial role advertisements play in connecting the viewer-consumers with the products during Covid times make it an essential part of our discussion as that traps us into a capitalist worldview.

The commodified nature of TV news can be inferred simply from how they have been attractively packaged for the viewers. ${ }^{19}$ The transition of both - news media and television content - to serve the populist imaginations and aspirations happened mainly due to their dependence on advertisement revenues. Primetime on TV continues to be the most preferred slots for advertisers. ${ }^{20}$ Advertisements during the covid-19 crisis tell us how the imagination of the pandemic is absorbed and appropriated into the dominant sense of reality that existed pre-covid. How were products marketed during the Covid-19 world?

Product marketing and promotion largely were based on misguided notion of scientificity. That some of the FMCG goods including sanitation products promised that $99.99 \%$ germs get killed. Needless to say, that they rode on the fear psychosis of the masses to sell their products. Vicks candies could kill germs, Facemasks became a fashion product, Dominoes promised safe distance delivery of Pizzas and E-commerce became the order of the day. Products and services were aiming to be 'covid-proof' to urge consumption. Not that they do not benefit the customers but beneath the marketing prudence lays a sheer opportunistic persuasion that appeals to 'the consumer-self'. The amount of immunity-boosting products that are in the market and how the

${ }^{18}$ See Financial Express (Sept 2, 2020). Advertisement on television rose 44\% in August when compared to June'20: TAM AdEx India 2020. https://www. financialexpress.com/brandwagon/advertisement-on-television-rose-44-inaugust-when-compared-to-june20-tam-adex/2072201/

19 M. Chaudhuri, Refashioning India: Gender, Media, and a Transformed Public Discourse, (Orient BlackSwan, 2017).

${ }^{20}$ See, AdEx India 2020; BARC India and Nielson 2020. 
older brands modified their products or just their taglines to suit the viral times, is an example of how television aids our transmission into the post-covid world without much resentment.

The 12 weeks during the lockdown have shown record TV viewership, 22 per cent higher, compared to the pre-covid levels with a 7 per cent higher Daily Average Reach. ${ }^{21}$ Among the 307 million people who watched TV all 7 days a week, 68 million more people were added compared to the pre-covid levels (239 million). Total TV Consumption increased by 43 percent during the peak period (Week starting March 28 2020) over Pre-Covid levels. While television and advertisements have actively pushed consumption levels during covid times, governments used them to manage their political image. Around 163 million people watched the AyodhyaTemple Bhumi Puja live. ${ }^{22}$ The table below illustrates the widespread coverage of Prime Minister's address during the lockdown announcements and the power of television media in arbitrating this process of consent manufacturing among the governed.

${ }^{21}$ BARC India and Nielson 2020, 5.

${ }^{22}$ Ibid, 37. 


\section{4 / Saravanan Velusamy}

Salesian Journal of Humanities and Social Sciences, Vol. XI, No.2 (Dec 2020) ISSN: 0976-1861 | DOI: 10.51818/SJHSS.11.2020.13-33 | Page: 13-33,

Section: Articles

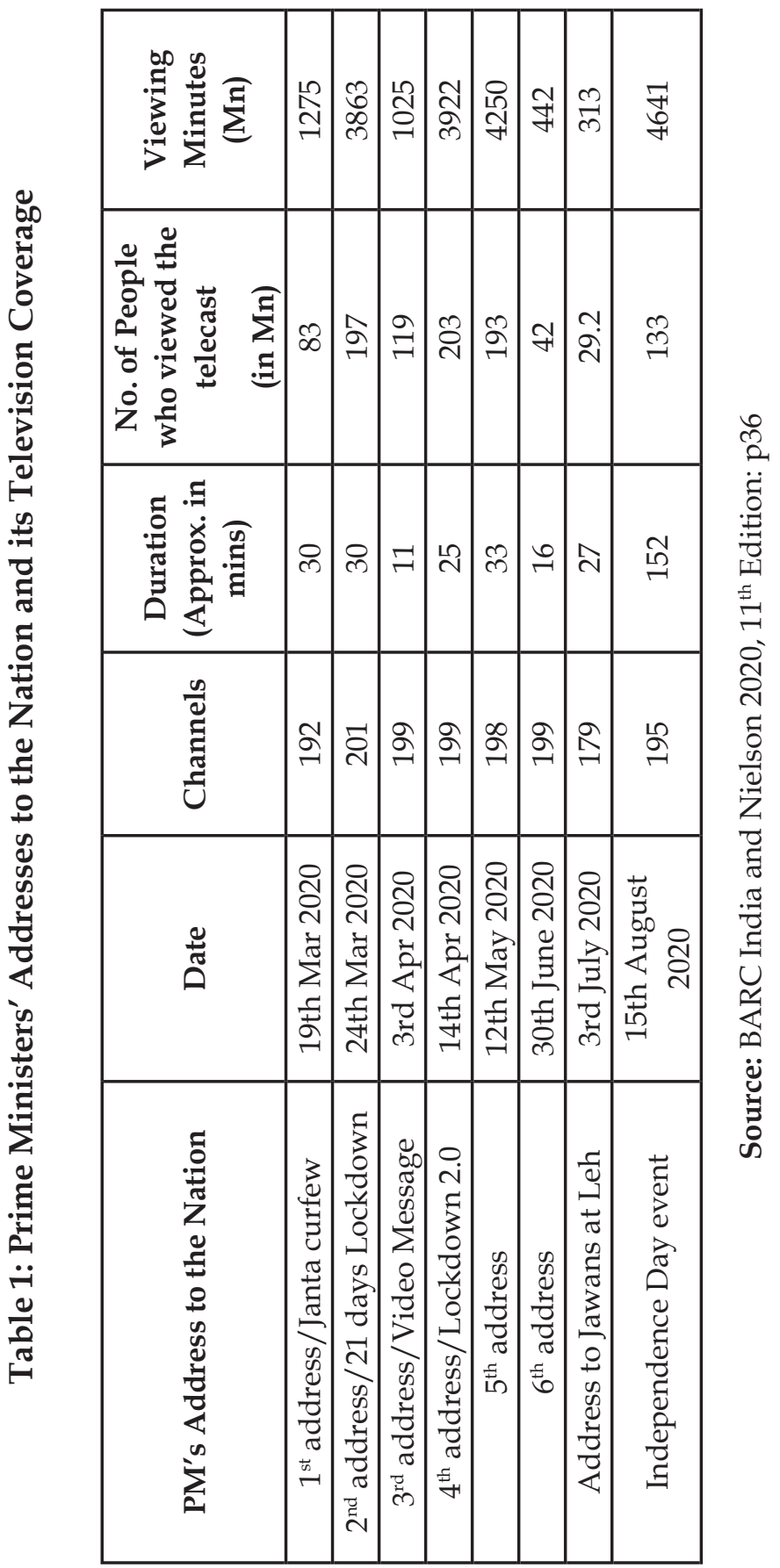


Media, Power and the Pandemic: Production ofFear, Discipline and a Distraught Self/ 25

Salesian Journal of Humanities and Social Sciences, Vol. XI, No.2 (Dec 2020)

ISSN: 0976-1861 | DOI: 10.51818/SJHSS.11.2020.13-33 | Page: 13-33,

Section: Articles

\section{Part III}

\section{Television Advertisements and Consumption during Covid-19}

Michael J Sandel, in his book, What Money Cannot Buy?asked how do we keep markets from encroaching our lives during times when everything is for sale? ${ }^{23}$ The moral limits of market that are often easily blurred by corporate brands in a society marked by conspicuous consumption often results in the invasion of our lives. The glamorous and appealing nature of the advertisements and their repetitive telecasting not only promotes consumption but also nudges us into a consumerist worldview. In such a view, it is okay to see everything as a product as long as it satisfies a certain need: from FMCGs to education (e-admissions and online classes) and healthcare, everything is for sale. There is a giant advertisement industry that helps do just that. The power that these dominant brands have with their ability to influence and control our lives cannot be overlooked. Since schools and colleges were asked to function online, many EduTech companies also used this crisis as an opportunity to raise their revenue.

Thanks to television advertisements, education has become a complete marketable commodity or a commercial service that relies on promotion. During lockdown EduTechcompanies organized a full-blown commercial campaign for online education and digital certification to open up the market for higher education in India. CoVid-19 has provided these platforms an excellent opportunity to proactively push for app-based educational products and services. India has over $3000+$ EduTech companies - the creamy layer of them all have high profile investors and their combined finance capital would certainly want to build a massive consumer base. Since March - when the first lockdown was imposed-BYJUs has added 6 million students to its digital learning platform ${ }^{24}$ and raised

${ }^{23}$ M.J. Sandel, "What money can't buy: The moral limits of markets," (New York: Farrar, Straus and Giroux, 2012).

${ }^{24}$ S.H.Salman, "Fresh funding round values Byju's at $\$ 10.5$ billion," Livemint, August 5, 2020. Retrieved August 13, 2020 from https://www.livemint.com/companies/ 


\section{6 / Saravanan Velusamy}

Salesian Journal of Humanities and Social Sciences, Vol. XI, No.2 (Dec 2020)

ISSN: 0976-1861 | DOI: 10.51818/SJHSS.11.2020.13-33 | Page: 13-33,

Section: Articles

around US\$ 545 million. The daily-fed advertisements to viewers with such ideas were a result of such investments.

Table 2: Notable Edu-Tech Investments during Covid-19 in India

\begin{tabular}{|c|c|c|}
\hline Company & Raised & From \\
\hline BYJUs & $\begin{array}{c}\text { US\$545 } \\
\text { million }\end{array}$ & $\begin{array}{c}\text { Bond Capital, General Atlantic and Tiger } \\
\text { Global, DST Global }\end{array}$ \\
\hline Unacademy & $\begin{array}{c}\text { US\$ } 110 \\
\text { million }\end{array}$ & Facebook and General Atlantic \\
\hline Univariety & $\begin{array}{l}\text { US\$1.1 } \\
\text { million }\end{array}$ & RTP Global et al \\
\hline Classplus & US\$9 million \\
\hline $\begin{array}{c}\text { White Hat } \\
\text { Jr. }\end{array}$ & $\begin{array}{c}\text { US\$ } 300 \\
\text { million }\end{array}$ & Bought by BYJUs \\
\hline
\end{tabular}

Source:Livemint and Business Standard 2020; Business Insider Sep 2, 2020.

Both sports and cinema celebrities, as brand ambassadors advance consumerism. In one such advertisement, two famous cricket stars were asking us to download a gaming app ${ }^{25}-$ Mobile Premier League aka MPL - so that unemployed youngsters can earn cash prizes by playing the game online. ${ }^{26}$ Can we expect celebrities to understand the seriousness of the country's unemployment crisis?

Here is a snippet of the job losses during April and May. The total unemployed youth grew from 9 million during 2011-12 to 25.1 million by $2017-18 .{ }^{27}$ By 2018 , more graduates (35.8\%) and

start-ups / fresh-funding-round-values-byju-s-at-10-5-billion-11596594521922.html ${ }^{25}$ Mobile Premier League (2019, April).Hero Bannahai? Toh MPL Khel Na-Cool Macha! Chrome Pictures Dir:Hemant Bhandari.[Video Ad].You Tube. Retrieved June 6, 2020 from https:// www.youtube.com/watch?v=wU5jKwnZ6lE

${ }^{26}$ Mobile Premier League, "Play Online with MPL - Office Ad - Mobile Premier League," 2019. Retrieved from YouTube on June 6, 2020 from https://www. youtube.com/watch?v=a38kP9YR4AY

${ }^{27}$ S. Mehrotr\& J.K. Parida, “India's employment crisis: rising education levels and 
Media, Power and the Pandemic: Production ofFear, Discipline and a Distraught Self/ 27

Salesian Journal of Humanities and Social Sciences, Vol. XI, No.2 (Dec 2020)

ISSN: 0976-1861 | DOI: 10.51818/SJHSS.11.2020.13-33 | Page: 13-33,

Section: Articles

postgraduates (36.2\%) were unemployed. By March 2020, the total employment figure fell to 396 million ( $2 \%$ drop) from its average 404 million during 2019-2020. This also fell to 144 million by April 2020 (30\% drop) according to Consumer Pyramids Household Survey. Companies have already communicated their decisions over cuts in salary and even job layoffs. The bottom of the pyramid-wage labourers, migrant workers, contract staff - were the worst affected. However, their stories were either not adequately carried by much of the national media nor were they given the weightage required when covered.

Naomi Klein, a journalist-turned researcher termed this disaster capitalism. Klein has reported from disaster zones in US to warn us how corporate firms find ways to profit from the disaster. Her shock doctrine to portend how authorities and industrialists use 'public's disorientation following a collective shock-wars, coups, terrorist attacks, market crashes or natural disasters - to push through radical pro-corporate measures, often called 'shock therapy'. ${ }^{28}$ Through facial recognition technology and drone technology, the way the current government actively rallied to create a police state with surveillance mechanisms imposed down its citizens during crisis, indicate the truth of Klein's assertion.

When the outbreak of the pandemic devastated the lives of the poor, the pro-government sections of the media constantly kept the people distracted. 68 thousand crores of defaults were written off by the government, various activists were arrested under the draconian UAPA (Unlawful Activities Prevention Act), dissenters and student protestors were also being jailed exposing them to the risk of infections. Migrant laborers died on their way home after walking several miles and the National Education Policy 2020 bill was passed at a time when students attempting suicides have risen due to the inaccessibility of online classes. Given the enchanting hold that television has upon its viewers - in suggesting that this

falling non-agricultural job growth", Center of Sustainable Employment, Azim Premji University, 2019.

${ }^{28}$ See, N. Klein, The shock doctrine: The rise of disaster capitalism,(USA:Macmillan,2007). 


\section{8 / Saravanan Velusamy}

Salesian Journal of Humanities and Social Sciences, Vol. XI, No.2 (Dec 2020)

ISSN: 0976-1861 | DOI: 10.51818/SJHSS.11.2020.13-33 | Page: 13-33,

Section: Articles

crisis is a temporary inconvenience-an absence of outrage among the masses comes as no surprise. Pandemic-like situations throw new challenges to a weakening democracy like India. How can one effectively dissent or protest against the government while in isolation? How do we ensure its effective response to the disaster or safeguard our rights when it pounces upon us? How does one remain sensitive during crisis amidst callous commercialism?

During the pandemic, the public, as subjects of governance, internalize the crisis and prepare to accept tough measures imposed upon them. John Dewey's book, The public and its Problems tend to validate Foucault's perspective that the ideals such as democracy envisaged by the modernity need not be rosy. It suffers from its own demerits. The strength of a democratic society lies in its people who have the power to elect their representatives to power. However, without a well-informed citizenship who can critically assess the social conditions and base their decisions on truth, they cannot assemble and organize consciously to modify the system to work for them; the purpose of democracy therefore remains unachieved leading to saturation and paralysis. To quote Dewey, "the new age of human relationships has no political agencies worthy of it. The democratic public is still inchoate and unorganized." ${ }^{29}$ This disorientation has to be seen in the light of media consumption as a social practice.

\section{Part IV}

\section{Debating the Media market}

India acts as an important market because of its consuming middle class and that makes it second largest online markets in the world. Around 600 million internet users constitute $50 \%$ internet penetration rate in the country by 2020 (as against 4 per cent in 2007), most of who are below 29 years of age who use mobile 
Media, Power and the Pandemic: Production ofFear, Discipline and a Distraught Self/ 29

Salesian Journal of Humanities and Social Sciences, Vol. XI, No.2 (Dec 2020)

ISSN: 0976-1861 | DOI: 10.51818/SJHSS.11.2020.13-33 | Page: 13-33,

Section: Articles

phones to access. ${ }^{30}$ There are more than 300 million Facebook users in India. ${ }^{31}$ The increase in internet penetration and accessibility also makes it a reliable marketplace.

New media emerged with the production of digitized contents online that gradually reached masses as widely as the smartphones reached Indian households. Indian market was 16 per cent of the global market share for smart phones by 2019. This was a sharp rise from 9 per cent in 2016. ${ }^{32}$ Internet penetration has also expanded to cover more population, especially the urban and the rural middle class into a web of digital communities. The phenomenon of digital sphere helped citizens mobilize against corruption and rape culture in the beginning of the decade culminating in marked political changes in the country. Social media acted as a powerful platform wherein the middle class youngsters could voice their views. The performance of the 'public' as active citizens, although largely dominated by the middle class, ${ }^{33}$ often isextended to social media platforms such as Twitter and Facebook. The sphere here is virtual and digital. News become tweets and vice versa. The embedded nature of television media and social media, therefore needs to be looked at as a whole as they depend on each other to shape public opinion in recent times.

Prabhat Patnaik (2002)observed in a convocation speech at Asian College of Journalism, Chennai ${ }^{34}$ that 'the moral universe of the media has shifted' because the people of this country have not only started

30 See, S. Keelery, "Internet Usage in India- Statistics \& Facts," July 7,2020. Retrieved August 5, 2020 from https://www.statista.com/topics/2157/internetusage-in-india/

${ }^{31}$ See, Statista, August 3, 2020.Retrieved August 5,2020 from ttps:/ / www.statista. com/statistics/255146/number-of-internet-users-in-india/ Aug 3, 2020

${ }^{32}$ IBEF, "Export Of Mobile Phones From India: Over 100\% Growth In Fy20" India Brand Equity Foundation, 2020. Retrieved July 30, 2020 from https:/ / www.ibef.org/ blogs/export-of-mobile-phones-from-india-over-100-growth-in-fy20

${ }^{33}$ M. Chaudhuri, "Indian media and its transformed public", Contributions to Indian Sociology 44, 1-2(2010): 57-78.

${ }^{34}$ See Editor,"Market, Morals andthe Media",Frontline, July 20, 2002. Retrieved August17, 2020 from https://frontline.thehindu.com/other/article30245622.ece 


\section{0 / Saravanan Velusamy}

Salesian Journal of Humanities and Social Sciences, Vol. XI, No.2 (Dec 2020)

ISSN: 0976-1861 | DOI: 10.51818/SJHSS.11.2020.13-33 | Page: 13-33,

Section: Articles

tolerating but also actively consuming the kind of sensationalism that has become common in the media world. Consumers of the new media today, consisting largely of the middle class have not only stopped looking for verifiable facts but have started basing their decisions on falsehoods masquerading as truth. The preference for disinformation that confirms ones beliefs-over verified information - keeps the environment vulnerable to fake news.

P.Sainath points out that the shift in this moral universe is also driven by the material universe of the corporate ownership.The might of the popular media driven by TRP rates is the might of the capital. The media corporations, with its marketing muscle and advertisement revenue, depend on the citizen-consumers and hence target them. The nexus between the political elites and the media elites has roots in the merging of the voter and the viewer. This interbreeding of the consuming citizens as both the voter and the viewer brings together the state and the market forces to defend and support each other.

Now, television media has gone digital and social media has also found its place in news reporting. The embedded nature of both is significant as TV media captures the housebound audience, the digitization of which carries the same to the mobile users. Did this not only compress time and space for instant reporting but also provided for a $24^{*} 7$ hold on the citizens as subjects of governance by the state? To keep them constantly on the loop is to establish modes of producing a self that is fashioned in favor of the state and the business class.

The numbing effect produced by the tragedy and the uncritical consumption of news create disorientation.Mazzarellaurges us to go beyond the standard opposition between liberal-progressive view based on impersonal ethics and the conservative-populist view based on the intimate realm. ${ }^{35} \mathrm{On}$ one side, there is a class of young citizenryregularly engaging and discussing on social

\footnotetext{
${ }^{35}$ W. Mazzarella, "Sense out of sense: Notes on the affect/ethics impasse", Cultural
} Anthropology 32, 2(2017): 199-208. 
Media, Power and the Pandemic: Production ofFear, Discipline and a Distraught Self/ 31

Salesian Journal of Humanities and Social Sciences, Vol. XI, No.2 (Dec 2020)

ISSN: 0976-1861 | DOI: 10.51818/SJHSS.11.2020.13-33 | Page: 13-33,

Section: Articles

media platforms. And, there is another set of citizens that consume television contents daily without much revulsion. This is not to say the public are not anguished of the injustice that occurs around them. These issues find place in the media and are being discussed and debatedat times. Comments werealso being shared across social media platforms along with the contents. Opinions of the public figures were being re-tweeted and shared widely. Both veneration and criticisms have found a place in the media sphere. However, whether it produced any nuanced debates around the issue, balance of perspectives or possibility for dialogic communication between the citizens and the state during the lockdown is to be seriously doubted.

Media, both TV and digital screens, became a battleground for ideologies, where a brute display of power is broadcasted daily and the citizen-consumers-as viewers and as users, choose which side they belong to. ${ }^{36}$ The need to subject the information to scrutiny and to arrive at truth is being disregarded in order to prove a point and win-whereas constructive criticism and meaningful analysis is limited only to a small section, the 'aware' civil society. Alternative Media that gains popularity among the elite sections of the civil society does thrive in the same digital sphere, yet they struggle to reach to the masses.

Consumption is the central social action that defines the citizenconsumers in India. The unquestioning self of a citizen-consumer is a product manufactured by the state and the media, financed by big capital. The objective is to produce citizen-consumers that are merely complying and hero-worshipping political subjects. Television Media in India plays a central role in social conditioning of the citizenry.It controls through a process of careful selection, censoring and framing to shape their understanding of the world. The dissemination of ideas through careful framing, television aids in the transfer of the ruling ideas of our times, especially when

36 See, Chaudhuri,"Mass Media,"Consortium for Educational Communication, University Grants Commission of India,June 14, 2018. Retrieved July 28, 2020 from https://www.youtube.com/watch?v=6FsBfEAT1GI 


\section{2 / Saravanan Velusamy}

Salesian Journal of Humanities and Social Sciences, Vol. XI, No.2 (Dec 2020)

ISSN: 0976-1861 | DOI: 10.51818/SJHSS.11.2020.13-33 | Page: 13-33,

Section: Articles

controlled by state and market agents. Thus, successfully passing over the dominant patterns of 'normalcy' of the pre-covid era into the post-covid world.

\section{Conclusion}

Television Media played a significant role not only in providing news about Covid-19 but also in shaping the public consciousness during that time. Pandemic coverage was certainly a priority for several news channels, however the framing and packaging of the arguments and the way government response and policies were passed over without adequate discussions and criticisms makes them a hand-in-glove partner in upholding the ideology of the state and market forces, as they increasingly are embedded within these institutions. The ruling dispensation, the TRP-driven Media and the corporate brands could successfully fashion an uncritical yet passively consuming and disoriented self-because it could not comprehend the disruptive changes that is unfolding; yet distraught by the daily reports of death and despondency. People were made to internalize the unprecedented and extraordinary nature of the crisis and were getting gradually primed and prepared for the tough measures to come, all through the medium of television. For news and entertainment, television remains the top option as it covers around 780 million of the population in India.

The year 2020 is momentous to Indian Democracy for it brought out the shadow side of its population and polity, Covid-19 is only a catalyst. This is a rare moment in history where the pandemic and its consequences have even reached the remote areas in the country. It has forced us to reflect on our social life. The mass consumption of fear, anxiety and the tragedy that unfolded enforced upon us an idea of new normal. This idea is state-scripted, media produced and represented a simulated version of the reality that produced a distraught self. It primed the citizen-subjects to be prepared for the tough changes, those whichmay not be otherwise acceptable during 
Media, Power and the Pandemic: Production ofFear, Discipline and a Distraught Self/ 33

Salesian Journal of Humanities and Social Sciences, Vol. XI, No.2 (Dec 2020) ISSN: 0976-1861 | DOI: 10.51818/SJHSS.11.2020.13-33 | Page: 13-33,

Section: Articles

the pre-covid times. It is grooming us to accept the new reality brought about by the pandemic and tolerate state action, however unacceptable it might seem in a constitutional democracy.

While the daily reports of death statistics and official announcements gave a false sense of transparency, the degree to which information is controlled by state agencies narrates a scenario otherwise. Media is a crucial ideological apparatus that linked the state agencies and the business class in connecting with the citizenconsumers and keeping them engaged, such that the politically influential middle class remains unagitated. The theatrics of the State requires a stage; television is the only widespread device that can provide for an audio-visual medium of that scale. 